\title{
Erosive adenomatosis of the nipple
}

\author{
Adenomatose erosiva do mamilo
}

\author{
Mayara Schulze Cosechen ${ }^{1}$ \\ Flávio Meingast Piva ${ }^{3}$ \\ Sérgio Zuneda Serafini ${ }^{5}$
}

\author{
Adma Silva de Lima Wojcik ${ }^{2}$ \\ Betina Werner ${ }^{4}$
}

\begin{abstract}
Erosive adenomatosis of the nipple is a complex benign mammary proliferation that can be misdiagnosed as a malignant mammary neoplasm. The most common clinical presentation includes discharge, erythema, erosion and crusting. The process is usually asymptomatic. It resembles benign conditions such as contact dermatitis, psoriasis and infections, but its main differential diagnosis is Paget's disease. Treatment is usually surgical and the prognosis is excellent.

Keywords: Adenoma; Breast; Breast Diseases; Histology

Resumo: A adenomatose erosiva do mamilo é uma complexa proliferação benigna mamária que pode ser confundida com neoplasias malignas da mama. A apresentação típica cursa com descarga mamária, eritema, erosão e formação de crostas. O processo é geralmente assintomático e de instalação insidiosa. A adenomatose erosiva do mamilo pode ser confundida com condições benignas, como a dermatite de contato, psoríase e infecções, mas seu principal diagnóstico diferencial é a Doença de Paget. O tratamento é cirúrgico e o prognóstico, excelente.

Palavras-chave: Adenoma; Doenças mamárias; Histologia; Mama
\end{abstract}

\section{INTRODUCTION}

Erosive adenomatosis of the nipple (EAN) is a rare disease caused by a complex proliferation of the lactiferous ducts that affects primarily middle-aged women. ${ }^{1-4}$ It can be confused clinically with Paget's disease and histologically with malignant mammary neoplasia and sweat gland tumors. ${ }^{2-6}$ A correct diagnosis is fundamental to avoid unnecessary major surgery, which can increase treatment morbidity and harm the patient. ${ }^{1,4-6}$

\section{CASE REPORT}

A 43-year-old female patient was referred to the
Dermatology Service with a lesion on her right nipple. She reported that after giving birth five years previously there had been a steady increase in the size of this nipple, accompanied by itching, pain, superficial ulceration and a serosanguineous discharge. She described improvements followed by a deterioration of the clinical picture and had used various topical products and oral antifungal agents without any improvement. There were no systemic symptoms or comorbidities. Physical examination revealed a nodular, erythematous, friable lesion affecting the whole right nipple with superficial ulceration and crusting in

Received on 15.04.2010.

Approved by the Advisory Board and accepted for publication on 22.11.2010.

* Work carried out at Hospital de Clínicas, Federal University of Paraná (HC-UFPR), Curitiba, PR, Brazil.

Conflict of interest: None / Conflito de interesse: Nenbum

Financial funding: None / Suporte financeiro: Nenbum

Medical student, Federal University of Paraná (UFPR), Curitiba, PR, Brazil.

Dermatology resident, Hospital de Clínicas, Federal University of Paraná.

Pathology resident, Hospital de Clínicas, Federal University of Paraná (HC-UFPR), Curitiba, PR, Brazil.

Dermatopathology specialist accredited by the International Society of Dermatopathology - Holder of a master's degree in clinical surgery with a concentration in dermatopathology from the Federal University of Paraná (UFPR) - Volunteer lecturer on the Pathological Anatomy and Dermatology Courses and volunteer dermatopathologist in the Pathological Anatomy and Dermatology Services, Federal University of Paraná (UFPR), Curitiba, PR, Brazil. Associate professor, Dermatology Service, Department of Clinical Medicine, Federal University of Paraná (UFPR), Curitiba, PR, Brazil

(C)2011 by Anais Brasileiros de Dermatologia 
places (Figures 1 and 2). Breast palpation failed to reveal any masses, and clinical axillary lymph node examination was negative.

Gram stain revealed the presence of Gram-positive cocci and bacilli. Ziehl-Neelsen stain did not reveal acid-alcohol fast bacilli, and direct microscopic examination failed to reveal fungi. The findings of a mammography performed in the same year were benign.

Pathological examination revealed glandular formations aligned in a double layer of epithelial cells. The glands were lined with apocrine metaplastic epithelium formed by cuboidal cells with eosinophilic cytoplasm and an eosinophilic secretion produced by cell decapitation. The basal layer was made up of myoepithelial cells. This proliferation affected the whole dermis, suggesting a diagnosis of EAN (Figures 3 and 4$)$.

The lesion was excised and the wound healed by second intention. The patient is currently being followed up.

\section{DISCUSSION}

Initially described as florid papillomatosis of the nipple (FPN), the disease has been known by many names since it was first reported by Jones in 1955. ${ }^{4.8}$ In 1962 Handley and Thackray questioned Jones' findings because the original micrographs showed an adenomatous lesion. ${ }^{1}$ Shortly afterwards, Le Gal called the condition "erosive adenomatosis" because of the erosive nature of the lesion. ${ }^{1,2,4,9}$ The following names can be found in the literature: erosive adenomatosis of the nipple, papillary adenoma of the nipple, florid adenomatosis, florid papillomatosis of the nipple, subareolar duct papillomatosis, superficial papillary adenomatosis of the nipple and adeno-

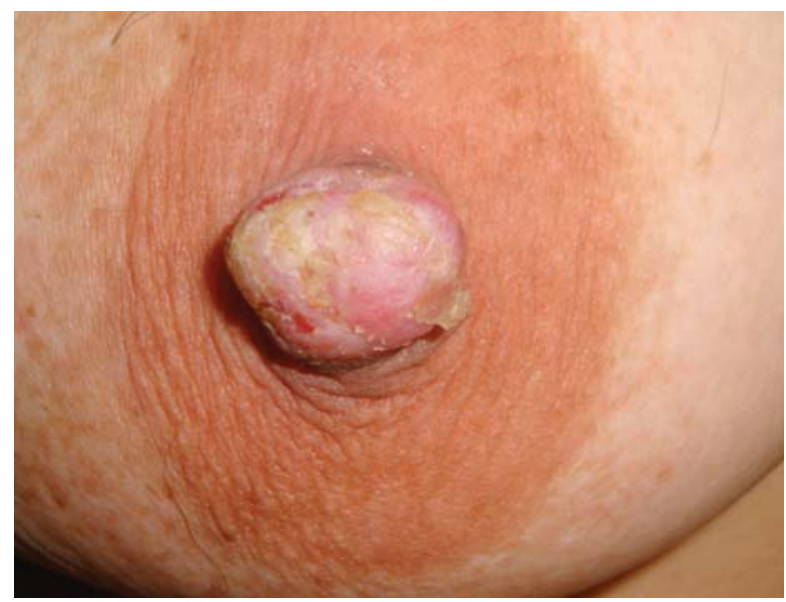

FIGURE 1: Front view: increased nipple volume, with erythema superficial ulceration and crusting

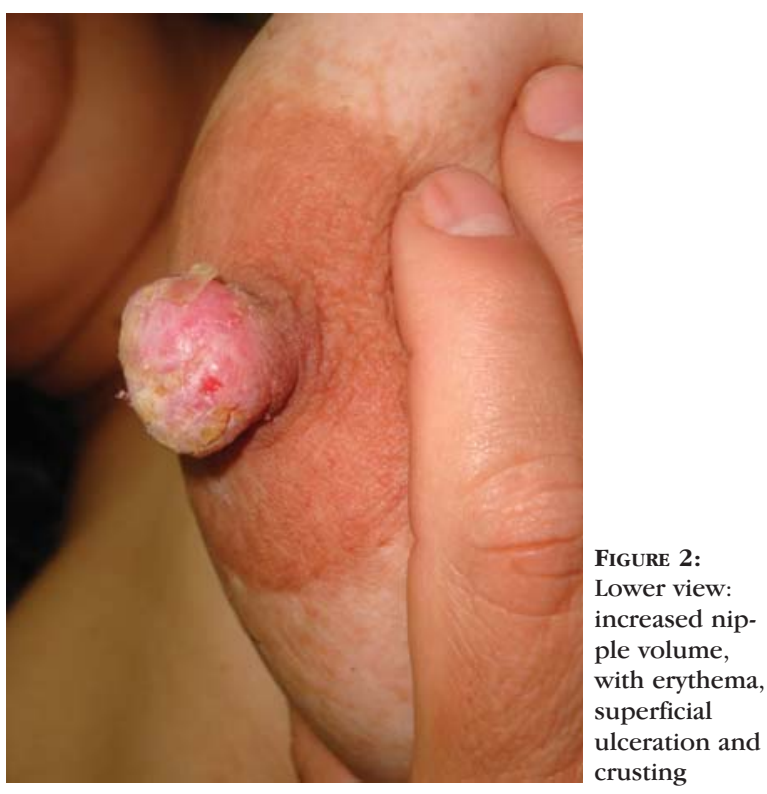

ma of the nipple, among others. ${ }^{1,2,4,5,7-9}$ Currently, the most commonly used term is erosive adenomatosis of the nipple (EAN). ${ }^{2}$

EAN is a rare, complex, benign proliferation of the lactiferous ducts. ${ }^{3}$ It occurs predominantly in women between forty and fifty years of age, with an average age of 45 years. ${ }^{1,3,4,7,8}$ It can on rare occasions be found in men and children ${ }^{1,4,5,7,8}$. Because of its insidious development, it is frequently found by chance and is usually diagnosed late. 3,4

The lesion can be completely asymptomatic. ${ }^{4,5,9}$ In patients who present with symptoms, the most common clinical findings are, in decreasing order, breast discharge (which can be serous, bloody or serosanguineous), crusting, erosions, the presence of nodules, pain and/or itching, edema and erythema. ${ }^{1,4,5,9,10}$ In the initial stages, the nipple can present with erosion, inflammation, erythema and a "broken" appearance. Itching and pain may be present during this phase. ${ }^{3,4,7}$, ${ }^{9}$ Symptoms may be exacerbated during the premenstrual period. ${ }^{3,8}$ During this stage the disease is clinically indistinguishable from Paget's disease of the breast. At a later stage the nipple has a firm (hard or elastic), nodular, deformed appearance like in our patient, allowing a differential diagnosis with other diseases. ${ }^{1,}$ 3,4,5,9 The disease usually occurs on one side only, but there are reports of lesions on both nipples.

Histological examination is fundamental for a diagnosis. ${ }^{6}$ Histologically, the lesion is characterized by intraductal proliferation invading the adjacent stroma. ${ }^{1,4}$ The most striking characteristic is the presence of two cell populations: an internal layer of cuboidal epithelial cells with an apocrine secretion and an 


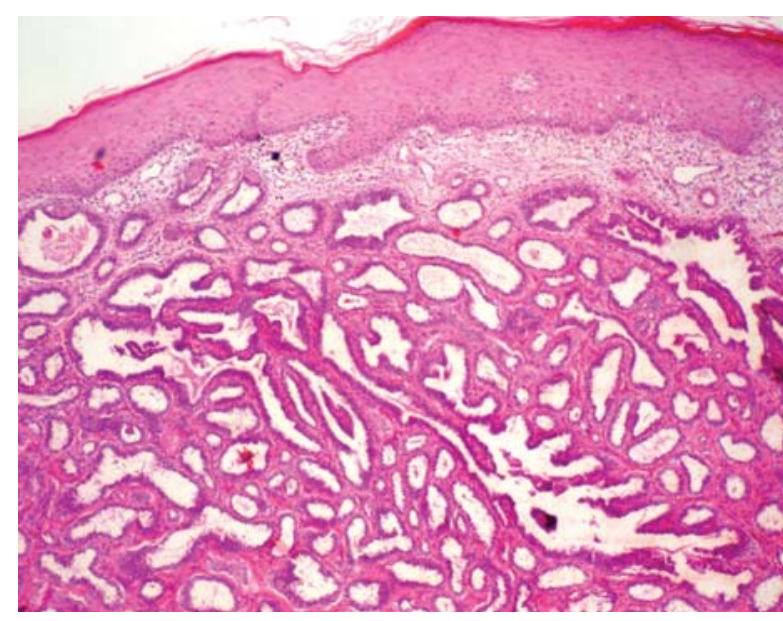

Figure 3: Glandular proliferation in the skin layers (HE, 40X, zoom 3.0X)

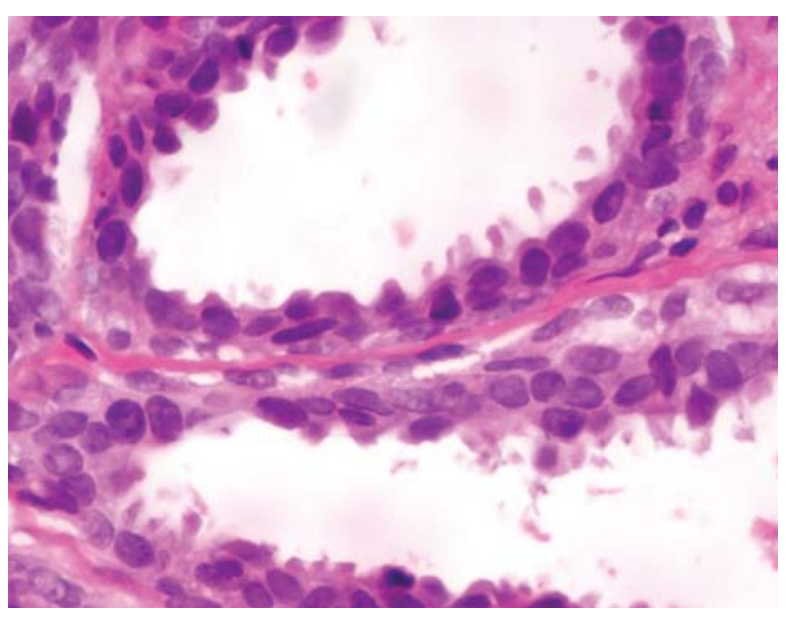

FIGURE 4: Apocrine glandular epithelium with decapitation secretion showing the two apocrine glandular cell populations (HE, 400X, zoom 3.0X) external layer of contractile myoepithelial cells. ${ }^{1,3,4,6,9}$ Erosion and ulceration may be present in 50\% of cases, and keratin cysts in less than 50\%. 1, 2, 4, 6 Cytological examination of the lesion can be performed; however, as it can be difficult to distinguish this kind of adenomatosis from intraductal papillomas, a biopsy remains the gold standard for diagnosis. ${ }^{11}$

Most authors consider the disease to be benign, with a risk of malignancy comparable to that in the rest of the female population. However, some maintain that the probability of developing neoplasms is still uncertain, and there are reports that the condition it is associated with and can progress to malignant disease. ${ }^{1,4,7,10,12}$ The above authors agree with most studies advocating a mammography or ultrasound examination for these patients. ${ }^{5,6,10}$

Immunohistochemistry tests and immunoperoxidase stains can be useful in establishing a differential diagnosis with malignant diseases. ${ }^{12}$ Anti-cytokeratin 1 antibody stains luminal epithelial cells, and antiactin, vimentin and glial fibrillary acidic protein bind to the myoepithelial layer. ${ }^{1,10,12}$ According to Moulin et al ${ }^{10}$, the essential difference between mammary carcinoma and EAN is that myoepithelial cells are not stained by anti-actin antibodies in the former. However, this method may not be useful in differentiating between EAN and other benign mammary proliferative lesions. ${ }^{7}$ Immunohistochemical studies were not carried out here as the diagnosis was typical.

There are many differential diagnoses for EAN, including inflammatory, infectious and neoplastic diseases. ${ }^{4}$ Clinically, the most important differential diagnosis is with Paget's disease, while histologically it is with malignant mammary neoplasms and tumors of the apocrine glands. 1,4,5,8,10
In the past, diagnostic errors led to unnecessary major surgery, increasing treatment morbidity. ${ }^{1,5}$ Nowadays, the treatment of choice is a simple resection of the tumor with a local anesthetic. ${ }^{1,5,-9,11}$ A curative excision usually removes the whole nipple as well as the underlying tissue. The nipple can then be reconstructed. Resection usually changes the ductal architecture, and women of childbearing age can lose the ability to breastfeed with this nipple after resection. ${ }^{1}$ There are reports of recurrence when the excision is incomplete. ${ }^{1,2}$ EAN can be treated with cryosurgery, and there are descriptions in the literature of successful treatment using this technique with two 45-second cycles followed by repeat treatment 2 months later. 9,13 There was no relapse in seven years. Mohs micrographic surgery (MMS) is a good treatment choice for localized disease as it allows the tumor to be excised completely, thus reducing the risk of recurrence, while at the same time allowing the breast structure to be preserved. Subsequent reconstruction can therefore be more easily performed, a factor that can be of particular importance for women of childbearing age. A purse-string suture can be used to close the incision after circular excision of the lesion. ${ }^{2,8}$

Although a rare condition, EAN has been gaining ever greater recognition. The role of the dermatologist in the diagnosis and treatment of the disease has become increasingly important in recent years as a result of reports of successful treatment with cryotherapy and MMS. It is therefore important that dermatologists, dermatological surgeons and dermatopathologists are familiar with this condition. $\square$ 


\section{REFERENCES}

1. Montemarano AD, Sal P, JamesD. Superficial papillary adenomatosis of the nipple: a case report and review of the literature. J Am Acad Dermatol. 1995;33:871-5.

2. Lee HJ, Chug KY. Erosive adenomatosis of the nipple: Conservation of the nipple by Mohs micrographic surgery. J Am Acad Dermatol. 2002;47:578-80.

3. Ward KA, Burton JL. Dermatologic Diseases of the Breast in young women. Clin Dermatol. 1997;15:45-52.

4. Albers SE, Barnard M, Thorne P, Krafchik BR. Erosive adenomatosis of the nipple in an eight-year-old girl. J Am Acad Dermatol. 1999;40:834-7.

5. Mattar D, Romero G, Betancourt L, Paredtes R, Zénzola VLR, Carrera Z, et al. Adenomatosis erosiva del pezón: reporte de un caso. Rev Venez Oncol. 2006;18:115-9.

6. El Idressi F, Fadli A. Adénomatose Érosive du mamelom. J Gynecol Obstet Biol Reprod. 2005;34:813-4.

7. Davies GL, Sacks NP, Gordon AB, Trott PA. Erosive adenomatosis of the nipple - a report of three cases. Ann R Coll Surg. 2004;86:146-7.

8. Ku BS, Kwon OE, Kim DC, Song KH, Lee CW, Kim KH. A cade of erosive adeno matosis of the nipple treated with total excision using purse-string suture. Dernatol Surg. 2006;32:1093-6.

9. Kuflik EG. Erosive adenomatosis of the nipple treated with cryosurgery. J Am Acad Dermatol. 1998;38:270-1.

10. Moulin G, Darbon P, Balme B, Frappart L. Erosive adenomatosis of the nipple. Report of 10 cases with immunohistochemistry. Ann Dermatol Venearol. 1990;117: 537-45

11. Kijima Y, Matsukita S, Yoshinaka H, Owaki T, Aikou T. Adenoma of the nipple: report of a case. Breast Câncer. 2006;13:95-9.

12. Moulin G. Superficial papillary adenomatosis of the nipple (with reply). J Am Acad Dermatol. 1997:36:133.

13. Moraes AM, Velho PENF, Magalhães RF. Criocirurgia com nitrogênio líquido e as dermatoses infecciosas. An Bras Dermatol. 2008;83:285-98.
MAILING ADDRESS / ENDEREÇO PARA CORRESPONDÊNCIA:

Mayara Schulze Cosechen

Rua Francisco Juglair, 410 - Apartamento 101

Mossunguê

81200230 Curitiba PR Brazil

E-mail:mayarasc@gmail.com

adma_lima@ibest.com.br / dermatologia@ufpr.br

How to cite this article/Como citar este artigo: Cosechen MS, Lima-Wojcik AS, Piva FM, Werner B, Serafini SZ. Erosive adenomatosis of the nipple. An Bras Dermatol. 2011;86(4 Supl 1):S17-20. 